\title{
ESTUDO COMPARATIVO DAS DIRETRIZES DOS CÓDIGOS FLORESTAIS DE 1965 E 2012
}

\author{
Carla Talita Pertille ${ }^{1}$ \\ Charles Costa Coelho² \\ Dionatan Gerber ${ }^{3}$ \\ Álvaro Boson de Castro Faria ${ }^{4}$ \\ Eleandro José Brun ${ }^{5}$
}

\section{RESUMO}

A legislação ambiental brasileira tem uma base de elaboração com solidez elevada, porém, ainda apresenta limitações, exigindo da sociedade e das instituições, ações que elas, muitas vezes, não são capazes de cumprir. O objetivo do trabalho foi gerar um documento que proporcione um melhor entendimento da legislação ambiental brasileira, especificamente aos Códigos Florestais de 1965 (Lei n 4.771/65) e 2012 (Lei $\left.n^{\circ} 12.651 / 12\right)$. Diversas alterações foram feitas, principalmente em relação aos regimes de proteção de áreas de preservação permanente (APP) e reserva legal $(\mathrm{RL})$. Dentre elas, o código atual define as providências iniciais que o produtor rural deve tomar para se adequar à legislação, como a inscrição no Cadastro Ambiental Rural (CAR). Com a aprovação do novo código, há uma necessidade de um trabalho contínuo nos âmbitos federal (regulamentações e atualizações), estadual e municipal (criação e regulamentação dos códigos florestais respectivos). Ressalta-se também a necessidade da implementação dos mecanismos de incentivos à preservação previstos no código atual, assim como uma atuação efetiva de profissionais com plenos conhecimentos sobre o Código Florestal.

Palavras-chave: área de preservação permanente, cadastro ambiental rural, reserva legal.

\footnotetext{
${ }^{1}$ Graduada em Engenharia Florestal (UTFPR). Mestranda em Engenharia Florestal (UDESC). E-mail: carla_pertille@hotmail.com.

${ }^{2}$ Graduando do Curso em Engenharia Florestal da Universidade Tecnológica Federal do Paraná (UTFPR). Email: ccoelho.florestal@gmail.com.

${ }^{3}$ Graduando do Curso em Engenharia Florestal da Universidade Tecnológica Federal do Paraná (UTFPR). Email: dionatan_gerber@hotmail.com.

${ }^{4}$ Graduado em Engenharia Florestal (UFPR). Mestre em Ciências Florestais (UFPR). Doutor em Ciências Florestais (UFPR). Professor do Departamento de Engenharia Florestal da Universidade Tecnológica Federa do Paraná (UTFPR). E-mail: alvarob@utfpr.edu.br.

${ }^{5}$ Graduado em Engenharia Florestal (UFSM). Mestre em Engenharia Florestal (UFSM) Doutor em Engenharia Florestal (UFSM). Professor do Departamento de Engenharia Florestal da Universidade Tecnológica Federal do Paraná (UTFPR). E-mail: eleandrobrun@utfpr.edu.br
} 


\title{
COMPARATIVE STUDY OF THE GUIDELINES OF FORESTRY CODES 1965 AND 2012
}

\begin{abstract}
Brazilian environmental legislation has a basis of elaboration with high solidity; however, it still presents limitations, demanding from society and institutions, actions that they, often, are not able to fulfill. The objective of the work was to generate a document that provides a better understanding of the Brazilian environmental legislation, specifically to the Forest Codes of 1965 (Law n. 4.771 / 65) and 2012 (Law $n{ }^{\circ} 12.651 / 12$ ). Several changes were made, mainly in relation to the regimes of protection of areas of permanent preservation (APP) and legal reserve (RL). Among them, the current code defines the initial measures that the rural producer must take to conform to the legislation, such as the registration in the Rural Environmental Cadastre (CAR). With the approval of the new code, there is a need for continuous work in the federal (regulations and updates), state and municipal (creation and regulation of the respective forest codes). It is also necessary to implement the incentive mechanisms for preservation provided in the current code, as well as an effective action of professionals with full knowledge of the Forest Code.
\end{abstract}

Keywords: legal reserve, permanent preservation area, rural environmental register.

\section{INTRODUÇÃO}

O homem, desde os primórdios da civilização, já se preocupava com a salvaguarda e a conservação de seus recursos mais preciosos. Entre esses recursos, a natureza em todas as suas expressões, incluindo a terra, a água e as fontes de energia e de riqueza. Disciplinar o uso desses bens enseja o surgimento de convenções, acordos e leis ambientais (NINO; ANJOS, 2015).

A Política Florestal Brasileira tem como principal instrumento relacionado a proteção de florestas, o Código Florestal, que institui as regras gerais sobre as formas de exploração da vegetação nativa do território brasileiro. Essa lei apresenta duas modalidades de áreas protegidas: as Áreas de Preservação Permanente (APP) e a Reserva Legal (RL).

“As APP's são áreas cobertas ou não por vegetação nativa com a função de preservar os recursos hídricos, a paisagem, a estabilidade geológica, a biodiversidade, o fluxo gênico da fauna e da flora, proteger o solo e assegurar o bem-estar das populações humanas" (BRASIL, 2012, Art. $3^{\circ}, \S$ II). Essas áreas se localizam nos topos de morros, encostas, margens de rios, nascentes, etc., e nelas os recursos naturais não podem ser explorados, salvo casos específicos previstos em lei (Utilidade Pública, Interesse Social ou Atividades Eventuais ou de Baixo Impacto Ambiental).

A Reserva Legal diz respeito a uma fração de terra da propriedade rural que deve manter a vegetação nativa original para garantir a biodiversidade da área, protegendo a fauna e a flora e também permitindo seu uso sustentável. Os percentuais mínimos de $\mathrm{RL}$ em relação ao imóvel rural variam conforme a região de localização. Se o imóvel está localizado na Amazônia Legal, os percentuais são $80 \%$ (oitenta por cento) no imóvel situado em área de florestas, 35\% (trinta e cinco por cento) no imóvel situado em área de Cerrado; $20 \%$ (vinte por cento) em imóvel 
situado em área de Campos Gerais e 20\% (vinte por cento) nas demais regiões do País (BRASIL, 2012, Art. 12, § I e II).

O 1ํㅡódigo Florestal foi criado em 1934, durante o governo de Getúlio Vargas, e tinha características preservacionistas, estabelecendo o uso da propriedade em função do tipo florestal remanescente (BRASIL, 1934). Este código também abordou o conceito de florestas protetoras em uma propriedade, no entanto, não indicava o tamanho dessas florestas, mas dando claras indicações da intenção de criar um conjunto de regras específicas para o meio ambiente.

Ao longo do tempo, o Poder Público sentiu a necessidade de interceder e estabelecer alguns limites através da criação oficial de outro Código Florestal. Tais medidas visavam a proteção das florestas e dos recursos hídricos, sendo entendidas como um ponto de partida às definições posteriores que abrangem as Áreas de Preservação Permanente. Em 1961, objetivando elaborar uma nova lei florestal, um grupo de trabalho foi criado e o trabalho baseou-se em legislações de outros países. Esse processo resultou na promulgação do segundo Código Florestal Brasileiro, no dia 15 de setembro de 1965, através da Lei $n^{\circ}$ 4.771/1965 (VIANA, 2001).

Com este código, um importante disciplinador de atividades florestais foi criado, declarando as florestas existentes no território nacional como bens de interesse comum a toda a população, garantindo o direito de propriedade, além de determinar regras para a utilização, preservação e conservação das florestas e outras formas de vegetação em propriedades rurais, ou seja, as Áreas de Preservação Permanente (APP) e Reserva Legal (RL) (BRASIL, 1965).

Suas diretrizes foram seguidas por 47 anos, até o ano de 2012, quando foi instituído o Novo Código Florestal (Lei Federal $n^{\circ}$ 12.651/2012), o qual trouxe alterações em relação ao Código Florestal de 1965 (Lei Federal n 4.771/1965), principalmente no que se refere a Reserva Legal e Área de Preservação Permanente.

A legislação ambiental brasileira, apesar de poder ser considerada, em termos relativos, bem elaborada, apresenta limitações, eficiências e ineficiências, exigindo da sociedade e instituições, comportamentos e atitudes que elas não são capazes de cumprir, necessitando de apoio técnico profissional para que o cumprimento da mesma seja efetivado em todas as atividades que demandem o cumprimento de leis relativos ao uso dos recursos naturais. Pode-se dizer que a maioria dos problemas ambientais do Brasil não se apoia em falta de legislação, mas sim de fiscalização efetiva e de projetos específicos para ações na área de mitigação e compensação ambiental.

Dentro desse contexto, este trabalho objetiva proporcionar um melhor entendimento da legislação ambiental brasileira, especificamente quanto aos Códigos Florestais de 1965 (Lei $n^{\circ}$ 4.771/65) e 2012 (Lei $n^{\circ}$ 12.651/12), além de interpretar as normas legais referentes à APP e RL e destacar os benefícios ou desvantagens presentes na nova Lei. Objetiva também suprir a carência e/ou insuficiência de materiais bibliográficos referentes a este tema que possam auxiliar profissionais técnicos e proprietários rurais quanto ao Código Florestal Brasileiro.

\section{DESENVOLVIMENTO}

Esta pesquisa foi desenvolvida a partir de uma revisão bibliográfica acerca das duas legislações mencionadas. Para isso, foi realizada uma pesquisa bibliográfica conceituando: Áreas de Preservação Permanente (APP) e Reserva Legal (RL) com base em cada Código Florestal: extinto e atual. A pesquisa foi realizada em meio eletrônico, através de consultas no Diário Oficial da União e em páginas oficiais de órgãos públicos, como o Ministério do Meio Ambiente (MMA) do 
Governo Federal, para obter informações das legislações analisadas. Também foram utilizados livros, teses, dissertações, artigos científicos, publicações em sites e revistas especializadas.

As informações referentes as APP's e RL foram dispostas em forma de texto. Assim, obteve-se as diferenças referentes a APP e RL para cada código. A discussão foi baseada nesses tópicos e nas fontes de dados digitais acima mencionados.

\section{REVISÃO BIBLIOGRÁFICA}

\subsection{LEI № $4.771 / 65$}

\subsection{1. Áreas de Preservação Permanente}

Os primórdios conceituais do que se conhece hoje como APP surgiram em 1934, com a edição do primeiro Código Florestal (Decreto no 23.793/34). Por este Código, o que se considera "preservação permanente" estava prescrito no art. $4^{\circ}$, que se referia às florestas protetoras. Essas florestas, de acordo com a sua localização, serviam para conservar o regime das águas, evitar erosão e garantir a salubridade pública (BRASIL, 1934). Porém, o conceito de Área de Preservação Permanente, surgiu no Brasil através da Lei $n^{\circ} 4.771 / 1965$ (BRASIL, 1965).

Inicialmente, em 1965, as APP's eram conhecidas como "florestas de preservação permanente". Essa nomenclatura gerava ambiguidade na interpretação da norma jurídica, pois era considerado de preservação permanente apenas as formações vegetais compostas por florestas. Isso fazia com que a norma não fosse cumprida nos locais onde não havia vegetação florestal. Este fato gerou a substituição do termo antigo e consolidação da "Área de Preservação Permanente" (APP) nos textos legais vigentes.

A Medida Provisória (MP) 2.166-67, promulgada em 2001, consagrou a terminologia APP. Na antiga redação, áreas que não tinham cobertura florestal poderiam ser sujeitas a intervenção humana, sem a obrigatoriedade da preservação (BRANDÃO, 2001). Já com a redação da MP n².166-67 de 2001, toda área, mesmo aquela desprovida de vegetação, passou a ser, definitivamente, considerada de preservação permanente (BRASIL, 2001).

Segundo a redação da MP n².166-67 de 2001, a Área de Preservação Permanente é definida como (MP n².166-67/2001):

Art. 1: Área protegida nos termos dos arts. $2^{\circ}$ e $3^{\circ}$ desta Lei, coberta ou não por vegetação nativa, com a função ambiental de preservar os recursos hídricos, a paisagem, a estabilidade geológica, a biodiversidade, o fluxo gênico de fauna e flora, proteger o solo e assegurar o bem-estar das populações humanas.

Por este código, as APP's são classificadas em duas modalidades, de acordo com seus arts. $2^{\circ}$ e $3^{\circ}$. As APP's descritas no artigo $2^{\circ}$ do Código Florestal são as APP's legais, instituídas por Lei, caracterizando o local que deve ser mantido preservado, independentemente se há ou não cobertura vegetal (ABREU; OLIVEIRA, 2002; LEUZINGER, 2007). Essas APP's têm relação com a "situação" topográfica das áreas, quer esteja coberta ou não por vegetação e se situam ao longo dos rios e demais cursos d'água, sendo sua dimensão em função da largura do próprio curso d'água. Também existem as APP's situadas em topo de morros, 
nas encostas, nas restingas, nas bordas dos tabuleiros e em altitude superior a 1800 m (BRASIL, 1965). O regramento aplicável às APP's, de acordo com a referida Lei e a Resolução do CONAMA no 303/2002, juntamente com seus limites, pode ser visualizado na tabela 1.

Tabela 1 - Delimitação de Áreas de Preservação Permanente segundo a Lei $\mathrm{n}^{0}$ $4.771 / 65$, com base na largura do curso d'água e faixa de entorno nas demais categorias.

\begin{tabular}{cc}
\hline Categoria de APP & Limite $(\mathbf{m})$ \\
\hline Rios com menos de 10 metros & 30 \\
Rios com 10 a 50 metros & 50 \\
Rios com 50 a 200 metros & 100 \\
Rios com 200 a 600 metros & 200 \\
Rios superiores a 600 metros & 500 \\
Lagoas naturais & 50 \\
Reservatórios d'água naturais ou artificiais & 30 m em áreas urbanas e 100 m em áreas \\
Nascentes (entorno) & rurais \\
Restingas & 50 \\
Bordas de tabuleiros & 300 \\
\hline
\end{tabular}

Fonte: BRASIL (1965); CONAMA (2002).

Já 0 art. $3^{\circ}$ do Código Florestal de 1965 determinava que as APP's poderiam ser criadas por ter relação com a "finalidade" preservacionista e consideradas de preservação permanente as áreas declaradas por Ato do Poder Público, sendo as "APP's administrativas", instituídas por ato declaratório (ABREU; OLIVEIRA, 2002).

As APP's são instituídas sem se considerar a titularidade do bem, quer incidam em áreas públicas ou privadas, indistintamente e de acordo com as características que apresentam (CAVEDON, 2003).

A lei não exige a averbação das APP's em cartório de registro de imóveis, ao contrário do que ocorre com as áreas de RL. A Lei, por si só, já caracteriza a importância que deve ser dada a essas áreas, daí a não obrigatoriedade de sua averbação. Deve ficar evidente que são áreas que, de qualquer maneira, de acordo com a localização, são insusceptíveis de intervenção (BORGES et al., 2011).

No entanto, quando o imóvel adquirido após a promulgação do Código Florestal (Lei $\left.n^{\circ} 4.771 / 65\right)$ não tiver sua APP protegida, ele estará gravado pelo passivo ambiental e responderá pelas obrigações constituídas antes da aquisição da propriedade, isto é, a responsabilidade pela regularização ambiental é do proprietário.

A primeira normatização para a permissão do uso das APP's foi disposta no art. $4^{\circ}$ deste Código Florestal alterado pela Medida Provisória n 2.166-67 de 2001. Nessa norma, a supressão de vegetação em APP era permitida desde que devidamente caracterizada a utilidade pública ou o interesse social da área. Esta Medida Provisória também regulamentou o procedimento administrativo de autorização da supressão, uma vez que a permissão somente poderá ocorrer na inexistência de alternativa técnica e locacional do empreendimento (BRASIL, 2001).

No entanto, esse regulamento recebeu várias críticas por considerar apenas a "supressão de vegetação" em APP. O regulamento não trouxe e nem definiu os critérios que permitiriam promover a alteração de uma APP quando desprovida de vegetação, ficando estas últimas entendidas como áreas livres para qualquer tipo de intervenção. 
Visando sanar essa polêmica, o CONAMA, através da edição da Resolução $n^{\circ}$ 369/06, acrescentou ao termo "supressão de vegetação" o termo "intervenção". Assim, o termo intervenção em APP pode ser considerado tanto para atividades em APP's desprovidas de vegetação bem como aquelas com ocorrência de vegetação. Esta Resolução também trouxe novas classes no entendimento de utilidade pública e interesse social, bem como permitiu a intervenção eventual e de baixo impacto ambiental em APP. No entanto, esta intervenção devia ser autorizada pelo órgão ambiental, não podendo comprometer as funções ambientais naturais.

\title{
3.1.2. Reserva Legal
}

Em 1934, o $1^{\circ}$ Código Florestal definia a obrigatoriedade de reservar área de floresta no imóvel rural, para conciliar a preservação de área de floresta com o fornecimento de carvão e lenha, permitindo a supressão/corte de, no máximo, três quartos (75\%) da vegetação existente no imóvel (BRASIL, 1934).

A evolução do instituto da Reserva Legal possuiu alguns marcos históricos: ainda sob o jugo da coroa portuguesa, surgiram as chamadas ordenações manuelinas que perdurou até o advento do primeiro Código Florestal Brasileiro em 1934. Outro marco importante foi a Constituição da República, de 1988, que reconheceu a Reserva Legal como instrumento necessário para a conservação da biodiversidade (art. 225), como meio necessário para a preservação do meio ambiente para as presentes e futuras gerações.

A reserva legal $(R L)$ é uma modalidade de área protegida no Brasil, e conforme o texto do Código Florestal de 1965 (BRASIL, 1965, Art. $1^{\circ}$, §2 , inciso III), onde reserva legal é:

\begin{abstract}
a área localizada no interior de uma propriedade ou posse rural, excetuada a de preservação permanente, necessária ao uso sustentável dos recursos naturais, à conservação e reabilitação dos processos ecológicos, à conservação da biodiversidade e ao abrigo e proteção da fauna e flora nativas.
\end{abstract}

Segundo o referido diploma legal, a $\mathrm{RL}$ pode ser alocada de diferentes maneiras na propriedade rural (BRASIL, 1965, Art. 16º):

§ 4: a localização da $\mathrm{RL}$ deve ser aprovada pelo órgão ambiental estadual competente, ou mediante convênio, pelo órgão ambiental municipal ou outra instituição devidamente habilitada, devendo ser considerados, no processo de aprovação, a função social da propriedade, e os seguintes critérios e instrumentos, quando houver:

I - O plano da bacia hidrográfica;

II - O plano diretor municipal;

III - O zoneamento ecológico-econômico;

IV - Outras categorias de zoneamento ambiental; e

$\mathrm{V}$ - A proximidade com outra RL, APP, unidade de conservação ou outra área legalmente protegida.

O percentual de cada imóvel rural a ser mantido sob a forma de $\mathrm{RL}$ varia de acordo com o bioma e a região do país, sendo de $80 \%$ da área do imóvel situado sob domínio de floresta na Amazônia Legal, 35\% da área do imóvel no bioma do Cerrado na Amazônia Legal e $20 \%$ da área do imóvel localizado nas demais regiões 
do país. Nas reservas legais, o uso direto dos recursos é permitido, desde que seja feito sob a forma de manejo sustentável (BRASIL, 1965; BRASIL, 2001).

A criação, recuperação e manutenção das $R L$ em imóveis rurais contribuiu para conservar remanescentes dos ecossistemas brasileiros, reparando áreas onde os mesmos foram ocupados por atividades agropecuárias. Nesse sentido, são necessárias ações que visem a recuperação de funções ambientais como: regulação dos fluxos de água, manutenção dos ciclos biogeoquímicos, entre outros (VILLAMAYOR, 2003).

A supressão, exploração e localização da $R L$ foi contemplada neste Código Florestal, por força da Medida Provisória $n^{\circ}$ 2.166-67, de 2001, que alterou 0 parágrafo $2^{\circ}$ do artigo 16 , destacando à proibição de supressão da vegetação de reserva legal, autorizando apenas sua utilização sob o regime de manejo florestal sustentável (BRASIL, 2001).

Segundo redação dada por esta Medida Provisória, ao artigo 44 do Código Florestal, o proprietário ou possuidor de imóvel rural com área de floresta nativa inferior ao mínimo legal para compor a $\mathrm{RL}$, conforme percentuais previstos nos incisos I ao IV do artigo 16, pode recompor a floresta, conduzir a vegetação nativa ou a compensar com outra área equivalente, devendo adotar as seguintes alternativas, isoladas ou conjuntamente (BRASIL, 2001):

I - recompor a reserva legal de sua propriedade mediante o plantio, a cada três anos, de no mínimo 1/10 da área total necessária à sua complementação, com espécies nativas, de acordo com critérios estabelecidos pelo órgão ambiental estadual competente;

II - conduzir a regeneração natural da reserva legal; e

III - compensar a reserva legal por outra área equivalente em importância ecológica e extensão, desde que pertença ao mesmo ecossistema e esteja localizada na mesma micro bacia, conforme critérios estabelecidos em regulamento.

A terminologia Reserva Legal surgiu com a Medida Provisória $n^{\circ} 7.803$, de 18 de julho de 1989 (BRASIL, 1989), a qual também tornou obrigatória a averbação da $R L$ à margem da inscrição de matrícula do imóvel no registro de imóveis competente, sendo vedada a alteração de sua destinação, nos casos de transmissão, a qualquer título, ou de desmembramento da área. Importante salientar que a Política Agrícola, instituída pela Lei $n^{\circ} 8.171 / 91$, estabeleceu como um dos seus objetivos "proteger o meio ambiente, garantir o seu uso racional e estimular a recuperação dos recursos naturais" (art. $3^{\circ}$, IV), e definiu o prazo de trinta anos para recomposição das áreas de reserva legal devastadas e cultivadas pelos proprietários de imóveis rurais, conforme previsto no seu artigo 99 (BRASIL, 1991).

A caminhada legal referente às RL's culminou com o Decreto $n^{\circ} 6.514$, de 22/07/2008, que veio para sanar a lacuna deixada por este Código Florestal quanto ao prazo de averbação das referidas áreas na matrícula do imóvel rural. O Código dispunha sobre a obrigatoriedade de averbar, mas não o prazo de averbação. Sendo assim, o Decreto $\mathrm{n}^{\circ} 6.514$, alterado posteriormente pelo Decreto $\mathrm{n}^{\circ} 6.686$, de 10/12/08, estipulou como prazo limite o dia 11 de dezembro de 2009, para que os proprietários de imóveis rurais procedessem à averbação das RL's junto ao Registro de Imóveis competente, sob pena de multa (VIANA, 2001).

Em função da crise gerada a partir da publicação destes decretos, foi editado o Decreto $n^{\circ} 7.209 / 2009$, que instituiu o "Programa Federal de Apoio à Regularização Ambiental de Imóveis Rurais", também chamado "Programa Mais 
Ambiente", com a finalidade de ampliar o prazo anteriormente concedido (VIANA, 2001).

As questões referentes a RL no âmbito do Código Florestal de 1965 geraram diversas polêmicas e representavam, nessa época (entre meados de 2008 a 2012), a maior preocupação dos proprietários rurais, especialmente para aqueles que possuíam APP's em sua propriedade e eram obrigados a cumprir a lei quanto a estes quesitos. Mesmo com a prorrogação do prazo para sua averbação, eram esperadas alterações quanto ao Código Florestal, que ocorreu em maio de 2012, trazendo alterações significativas no que tange a $\mathrm{RL}$.

\subsection{LEI No $12.651 / 2012$}

\subsection{1. Área de Preservação Permanente}

Embora mantenha as mesmas distâncias do Código revogado, deve-se atentar que, pela nova legislação, a APP de cursos d'água é medida a partir da calha regular dos rios, ou seja, o canal por onde correm regularmente as águas do curso d'água durante o ano, e não mais a partir do leito maior que é aquele nível alcançado por ocasião da cheia sazonal (BRASIL, 2012). A regra geral considera APP's as margens de qualquer curso d'água natural perene e intermitente, exceto os efêmeros, ou seja, incluindo os que possuem intervalos irregulares (intermitente) e excluem pequenos cursos d'água natural de duração temporária. Para isso, deve-se observar desde a borda da calha do leito regular, nas larguras mínimas definidas na tabela 2 (BRASIL, 2012).

Tabela 2 - Delimitação de Áreas de Preservação Permanente segundo a Lei $\mathrm{n}^{\circ} 12.651 / 12$.

\begin{tabular}{cc}
\hline Largura do Rio $(\mathrm{m})$ & Largura da APP $(\mathrm{m})$ \\
\hline Menos de $10 \mathrm{~m}$ & 30 \\
De 10 a $50 \mathrm{~m}$ & 50 \\
De 50 a $200 \mathrm{~m}$ & 100 \\
De 200 a $600 \mathrm{~m}$ & 200 \\
Superior a $600 \mathrm{~m}$ & 500 \\
\hline
\end{tabular}

Fonte: BRASIL (2012).

A nova lei $12.651 / 2012$, em seu capítulo XIII art. $63^{\circ}$, referindo sobre o inciso $\mathrm{V}, \mathrm{VIII}, \mathrm{IX}$ e $\mathrm{X}$ do art. $4^{\circ}$, admite a regularização de usos nas áreas de APPs das encostas, topo de morro, campos de altitude e bordas de tabuleiros, possibilitando, a manutenção de atividades florestais, culturas de espécies lenhosas, perenes ou de ciclo longo, desde que essas atividades tenham sido realizadas antes da data 22 de julho de 2008, atribuída pela legislação como área rural consolidada e que, pela antiga lei $n^{\circ} 4.771 / 65$, não eram passíveis de regularização.

Com a atualização do Código Florestal e o Decreto no 7.830/2012, surgiu um conceito de suma importância: regularização ambiental. Este termo é definido como o "conjunto de atividades desenvolvidas e implementadas no imóvel rural que visem atender ao disposto na legislação ambiental, de forma prioritária, garantem a manutenção e recuperação de Áreas de Preservação Permanente (APP's), Áreas de Uso Consolidado (AURs) e Reserva Legal (RLs) e a compensação da RL, quando couber" (art. $2^{\circ}, \mathrm{XV}$, Decreto $\left.\mathrm{n}^{\circ} 7.830 / 2012\right)$.

$\mathrm{O}$ art. 61-A do Código Florestal diz respeito aos limites mínimos de regularização ambiental das APP's. Essa forma de regularização ficou também conhecida como "regra da escadinha". Tal regra considera que, nas áreas 
consolidadas (áreas em que a supressão (remoção) ocorreu até 22 de julho de 2008) a recomposição ou regeneração de APP's hídricas, será dimensionada conforme o tamanho do imóvel rural em Módulo Fiscal (MF) (BRASIL, 2012).

Assim, as pequenas propriedades (que possuem até quatro Módulos Fiscais (MFs)), deverão recompor as faixas marginais, contadas da borda da calha do leito regular, independentemente da largura do rio, em até cinco metros (propriedades de até $1 \mathrm{MF}$ ), em até oito metros (propriedades com área superior a 1 módulo até $2 \mathrm{MF}$ ) e até 15 metros (propriedades com área superior a 2 e até $4 \mathrm{MF}$ ) (BRASIL, 2012).

Deve-se ressaltar que, de acordo com o art. 61-B do Código Florestal, aos imóveis rurais que, em 22 de julho de 2008, detinham até 10 módulos fiscais (MF) e desenvolviam atividades agrossilvipastoris nas áreas consolidadas em APP é garantido que a exigência de recomposição, somadas todas as APP's do imóvel, é obrigatória somente até os limites:

I - $10 \%$ da área total do imóvel, para imóveis rurais com área de até $2 \mathrm{MF}$;

II - 20\% da área total do imóvel, para imóveis rurais com área de 2 a 4 MF.

De acordo com a lei $n^{\circ} 12.651 / 2015$, Capitulo XIII, seção III das áreas consolidadas em APP, em propriedades com até $4 \mathrm{MF}$, a recomposição da APP pode ser realizada com uso de espécies nativas e exóticas, e para as propriedades com área superior a 4 MF onde, apesar da faixa de recomposição ser a mesma (15 metros), é permitido somente o uso de espécies nativas (BRASIL, 2012).

Em relação às APP's de relevo, no que diz respeito às encostas, a legislação manteve o conceito de: "são protegidas as encostas ou parte destas, com declividade superior a $45^{\circ}$, equivalente a $100 \%$ na linha de maior declive" (BRASIL, 1965; 2012).

A nova lei alterou o conceito de topo de morro, sendo que são protegidos agora o terço superior de elevações com altura mínima de 100 metros e inclinação média maior que $25^{\circ}$, sendo a altura da elevação (topo) medida em relação à base (definida pelo ponto de cela) e a declividade média do morro.

Para veredas, a regra geral é que, para as novas supressões, são consideradas APP's, a faixa marginal, em projeção horizontal, com largura mínima de 50 metros, a partir do espaço permanentemente brejoso e encharcado (BRASIL, 2012). E nas áreas consolidadas, onde ocorreu supressão até o dia 22 de julho de 2008, será obrigatória a recomposição das faixas marginais, em projeção horizontal de: trinta metros, para as propriedades com área de até 4 MF e cinquenta metros, para as propriedades com área acima de 4 MF (BRASIL, 2012).

Esta recomposição exigida pelo novo Código pode ser feita pelos seguintes métodos (BRASIL, 2012):

1) Condução da regeneração natural de espécies nativas;

2) Plantio de espécies nativas;

3) Plantio de espécies nativas, conjugado com a condução da regeneração natural de espécies nativas;

4) Plantio intercalado de espécies lenhosas; perenes ou de ciclo longo; e exóticas com nativas de ocorrência regional, em até $50 \%$ da área total a ser recomposta, nas pequenas propriedades ou propriedade familiar.

Com estas alterações propostas pelo novo Código, em termos gerais e estruturais, a lei propõe ajustes pontuais para adequação da situação de fato à situação de direito pretendida pela legislação ambiental. 


\title{
3.2.2. Reserva Legal
}

O Código vigente a partir de 2012 não alterou a área que o proprietário rural deve manter com cobertura vegetal nativa a título de RL.

O $\S 8^{\circ}$ do art. 16, do Código Florestal revogado (Lei $\left.n^{\circ} 4.771 / 1965\right)$, após redação dada pela Medida Provisória $n^{\circ}$ 2.166-67/2001, determinava que a área de $\mathrm{RL}$ deveria ser averbada à margem da inscrição de matrícula do imóvel, no registro de imóveis competente. O objetivo era mostrar os limites da reserva em um instrumento público, cujo acesso às informações fosse livre para quem tivesse interesse (STEPHANES, 2012).

Tamanha era a importância da averbação da $R L$ no registro de imóveis que o Decreto Federal $n^{\circ} 6.686 / 2008$ passou a tipificar como infração a não averbação da RL. Contudo, o Novo Código Florestal (Lei $n^{\circ} 12.561 / 2012$ ) desobrigou a averbação à margem da matrícula do imóvel, o que pode ser observado em seu art. 18:

\begin{abstract}
Art. 18. A área de Reserva Legal deverá ser registrada no órgão ambiental competente por meio de inscrição no CAR de que trata 0 art. 29, sendo vedada a alteração de sua destinação, nos casos de transmissão, a qualquer título, ou de desmembramento, com as exceções previstas nesta Lei (BRASIL, 2012).
\end{abstract}

A implantação do Cadastro Ambiental Rural (CAR) pelo Código Florestal (Lei $n^{\circ}$ 12.651/2012) desobrigou a averbação da reserva legal no registro de imóveis. Agora os proprietários de imóvel com $\mathrm{RL}$ conservada e inscrita no CAR cuja área ultrapasse o mínimo exigido pela lei 12.651/2012, poderá utilizar a área excedente para Cota de Reserva Legal, sem a necessidade da averbação. Quanto à natureza do CAR, cumpre esclarecer que é um ato declaratório obrigatório (art. $6^{\circ}$, Decreto $n^{\circ} 7.830 / 2012$ ) que todo proprietário, possuidor rural, ou representante legalmente constituído deve fazer no prazo de um ano (art. $6^{\circ}, \S^{\circ}$, Decreto $\mathrm{n}^{\circ}$ $7.830 / 2012$ ) contado a partir do dia 06/05/2014, quando foi implantado (art. 64 da IN $n^{\circ}$ 02/2014 do MMA). Porém, desde então, o prazo para a realização do CAR já passou por várias prorrogações e, com a Lei $n^{\circ} 13.335 / 2016$, o prazo para a realização do CAR, foi estendido para 31 de Dezembro de 2017, prazo este que é válido apenas para os pequenos produtores rurais e agricultores familiares, com área de até quatro módulos fiscais.

O Novo Código Florestal não alterou o conceito de averbação da RL, somente garantiu direito a sua gratuidade $\left(\S 4^{\circ}\right.$, art. 18, BRASIL, 2012). Para conclusão do processo de averbação da $R L$, faz-se necessário o registro da mesma na escritura do imóvel, porém, antes disso, é necessária a aprovação da RL pelo órgão ambiental competente. Sendo assim, tem-se três possíveis situações:

- Imóvel Rural sem Reserva Legal averbada: aquele que, por motivos diversos, não apresenta nenhum documento comprobatório de que parte da vegetação nativa da propriedade ou posse se destine à composição da RL:

- Imóvel Rural com Reserva Legal aprovada, porém não averbada: aquele que possui remanescente de vegetação nativa destinado para $R L$, com aprovação por parte do órgão ambiental competente, todavia sem registro à margem do documento de propriedade ou posse.

- Imóvel Rural com Reserva Legal aprovada e averbada: aquele que possui remanescente de vegetação nativa destinado para $R L$, com aprovação por parte do órgão ambiental competente e registrado à margem do documento de registro. 
A averbação pode ser feita na própria matrícula do imóvel, caso este possua remanescente de vegetação nativa, ou pode ser feita na matrícula de outro imóvel, independente do motivo. Essa situação é denominada "compensação" (BRASIL, 2012).

A compensação da Reserva Legal é um mecanismo pelo qual o proprietário ou possuidor pode regularizar sua $\mathrm{RL}$, adquirindo áreas equivalentes em outro imóvel rural, em vez de destinar áreas de uso produtivo para regeneração natural ou recomposição (BRASIL, 2012).

As áreas a serem utilizadas para compensação deverão atender aos seguintes requisitos (Lei $n^{\circ} 12.651 / 2012$, Art. $66 \S^{\circ}$ e $6^{\circ}$ ):

I. Serem equivalentes em extensão à área da $R L$ a ser compensada;

II. Estar localizada no mesmo bioma da área de RL a ser compensada;

III. Se fora do Estado, estar localizada em áreas identificadas como prioritárias para conservação, pela União ou pelos Estados, buscando favorecer a recuperação de bacias hidrográficas excessivamente desmatadas, o estabelecimento de corredores ecológicos, a conservação de grandes áreas protegidas e a conservação ou recuperação de ecossistemas ou espécies ameaçadas.

A compensação pode ser feita de três formas: aquisição de Cota de Reserva Legal (CRA); arrendamento da área sob regime de servidão ambiental ou $\mathrm{RL}$; e doação ao poder público de área localizada no interior de Unidade de Conservação (UC) de domínio público pendente de regularização fundiária (BRASIL, 2012).

De acordo com o atual Código Florestal (Lei $n^{\circ}$ 12.651/2012) àqueles proprietários ou possuidores de imóvel rural, que detinham, em 22 de julho de 2008 , área de Reserva Legal em extensão inferior ao exigido de acordo com seu bioma e região devem regularizar essas áreas.

Para os imóveis rurais que detinham, em 22 de julho de 2008, área de até quatro módulos fiscais (consideradas pequenas propriedades), e que possuíam remanescente de vegetação nativa em percentuais inferiores ao previsto em lei, a $\mathrm{RL}$ pode ser constituída pela área ocupada com a vegetação nativa existente até essa data. Nesse caso, o proprietário ou possuidor não deve suprimir qualquer remanescente de vegetação nativa no seu imóvel para uso alternativo do solo, previsto no artigo 67 do capítulo XIII do atual Código Florestal (Lei n 12.651/2012). Para propriedades com mais de quatro MF, o percentual de $\mathrm{RL}$ a ser mantido continua sendo de $20 \%$, regra geral para qualquer bioma fora da Amazônia Legal. Por outro lado, o percentual de RL a ser mantido em uma área dentro do bioma fora da Amazônia Legal deve ser: $80 \%$ do imóvel situado em área de florestas, 35\%, do imóvel situado em área de cerrado e $20 \%$, no imóvel situado em área de campos gerais. Esse processo de regularização está simplificado na tabela 3. 
Tabela 3 - Regularização ambiental para Reserva Legal conforme Lei Federal $\mathrm{n} 012.651 / 2012$.

\begin{tabular}{|c|c|c|c|}
\hline \multicolumn{2}{|c|}{ Amazônia Legal } & \multicolumn{2}{|c|}{ Demais Regiões } \\
\hline $\begin{array}{l}\text { Propriedades }<4 \\
\text { MF }\end{array}$ & Propriedades $>4 \mathrm{MF}$ & Propriedades < 4 MF & Propriedades $>4 \mathrm{MF}$ \\
\hline $\begin{array}{l}\text { Considera-se } \\
\text { regularizada } \\
\text { desde que } \\
\text { mantenha, no } \\
\text { mínimo, o } \\
\text { percentual em } \\
\text { área ocupada por } \\
\text { remanescente de } \\
\text { vegetação nativa } \\
\text { estabelecido em } \\
22 \text { de julho de } \\
2008 .\end{array}$ & $\begin{array}{l}\text { A porcentagem } \\
\text { dependerá do bioma } \\
\text { no qual o imóvel } \\
\text { rural está inserido: } \\
\text { I: } 80 \% \text { na } \\
\text { propriedade rural } \\
\text { situada em área de } \\
\text { floresta; } \\
\text { II: } 35 \% \text { na } \\
\text { propriedade rural } \\
\text { situada em área de } \\
\text { cerrado; } \\
\text { III: } 20 \% \text { na } \\
\text { propriedade rural em } \\
\text { área de campos } \\
\text { gerais. }\end{array}$ & $\begin{array}{l}\text { Considera-se } \\
\text { regularizada desde } \\
\text { que mantenha, no } \\
\text { mínimo, o percentual } \\
\text { em área ocupada } \\
\text { por remanescente de } \\
\text { vegetação nativa } \\
\text { estabelecido em } 22 \\
\text { de julho de } 2008 \text {. }\end{array}$ & $\begin{array}{l}\text { I: } 20 \% \text { na } \\
\text { propriedade rural } \\
\text { situada em área de } \\
\text { floresta ou outras } \\
\text { formas. }\end{array}$ \\
\hline
\end{tabular}

Com as alterações previstas por este código, com a extinção da averbação da Reserva Legal em cartório, ocorre a desburocratização deste processo, tornandoo mais acessível aos proprietários rurais. Além disso, a possibilidade de compensar a RL no bioma possibilita aos estados regularizarem suas áreas (STEPHANES, 2012).

\section{PRINCIPAIS MUDANÇAS}

Diversas alterações foram feitas ao Código Florestal de 1965, alterando principalmente os regimes de proteção de APP e RL. A principal medida foi a edição do Decreto no 6.514 de 2008, o qual discorre sobre as infrações e sanções administrativas ao meio ambiente e regulamenta o Código Florestal. Esse decreto contribuiu significativamente para a aplicação real do Código, pois estabeleceu regras sobre a regeneração de APP e RL e multas para quem impedisse essa regeneração (BRASIL, 2008).

A aprovação do novo código florestal promoveu diversas alterações em relação ao código extinto, considerando a produção agropecuária relacionada com o meio ambiente e suas particularidades. Diante do cenário de obrigatoriedade de adequação à nova legislação, surge a preocupação em como atendê-la, através da recuperação e proteção ambiental sem comprometer a viabilidade econômica da propriedade. Para isso, podem ser utilizados mecanismos de adequação, como o CAR (Cadastro Ambiental Rural), criado com o escopo de integrar as informações ambientais das propriedades e posses rurais, feito em registro público eletrônico de âmbito nacional e o PRAD (Projeto de Recuperação de Áreas Degradadas) que visa restaurar uma área degradada para amenizar os efeitos da degradação no meio ambiente.

Além de relacionar a preservação ambiental com a realidade rural, o novo Código Florestal reconheceu as florestas e demais formas de vegetação como bens de interesse comum a todos os habitantes do país, além da ação governamental de proteção e uso sustentável das florestas e responsabilidade de criação de políticas públicas para a preservação e restauração da vegetação nativa e suas funções 
ecológicas e sociais nas áreas urbanas e rurais, a recuperação da vegetação nativa e no desenvolvimento de atividades produtivas sustentáveis (BRASIL, 2012).

O novo código alterou algumas definições, como a pequena propriedade ou posse rural familiar, regulamentada no Art. 3ำ da Lei $11.326 / 06$, não podendo a área ser maior do que quatro módulos fiscais. Pelo código extinto, a Reserva Legal excluía de seu cômputo as APPs e, com o novo código, não existe mais essa limitação. Tal mudança permite a ampliação de atividades de utilidade pública e interesse social, as quais permitem a supressão de APP (BRASIL, 2012) mediante condições específicas.

A redação do Código anterior apresentava restrições nesse ponto, permitindo apenas a supressão de vegetação em APP em casos de utilidade pública ou interesse social, devidamente caracterizados e motivados em procedimento administrativo próprio. A previsão para a supressão de vegetação em APP em situações de supressão eventual ou de baixo impacto ambiental também era presente na legislação, mas deveria haver autorização do órgão ambiental competente, além da necessidade de adoção de medidas mitigadoras e compensatórias pelo empreendedor. O novo Código Florestal foi mais direto nesta questão, não mencionando procedimentos administrativos ou medidas mitigadoras e compensatórias a serem estabelecidas pelo órgão ambiental competente, aspecto que deverá ser disciplinado em orientações legais posteriores, de forma a ordenar o uso da APP.

Dentre as definições incluídas na nova legislação, a principal diz respeito a área rural consolidada, considerada como uma área de imóvel rural com ocupação antrópica preexistente a 22 de julho de 2008, com a substituição da vegetação nativa por outras coberturas do solo, como atividades agropecuárias, industriais e de geração de energia, mineração e transporte, assentamentos urbanos e também o manejo florestal (BRASIL, 2012).

Dentre as principais alterações no que diz respeito às APP, a mais relevante está na forma de delimitação. No código extinto a contagem era baseada no leito maior dos corpos d'água. No código atual, a medida deve ser considerada a partir do leito regular, o que, segundo os ambientalistas, interfere diretamente na área total a ser protegida. Além disso, o novo código também prevê áreas de proteção para as veredas (áreas úmidas), com uma faixa de vegetação de 50 metros a partir do trecho brejoso, o que não estava previsto na lei anterior e introduz áreas de apicuns e salgados na legislação, áreas usadas para carcinicultura e salinas, que não apareciam no código extinto (BRASIL, 2012).

Para reservatórios de água, o tratamento é diferenciado conforme o tamanho e o tipo (natural ou artificial). Nos reservatórios com menos de um hectare será dispensada a APP, a fim de solucionar o problema em pequenos açudes construídos em imóveis rurais para a dessedentação de animais. Já os reservatórios artificiais formados por represamento em imóveis rurais devem ter APP de no mínimo 15 metros, caso não sejam usados para o abastecimento público ou geração de energia elétrica e tenham até 20 hectares de superfície, conforme estabelecido no Art. 5, capítulo II do atual Código Florestal (Lei oㅜ 12.651/2012).

Quanto à Reserva Legal, o Código atual previu casos em que a mesma não será exigida, como para empreendimentos de abastecimento público de água e tratamento de esgoto ou para áreas adquiridas ou desapropriadas com o objetivo de implantação e ampliação da capacidade de rodovias e ferrovias, e casos em que o Poder Público poderá reduzir o percentual da Reserva Legal para até $50 \%$, quando - Município tiver mais de $50 \%$ da área ocupada por unidades de conservação da natureza de domínio público e por terras indígenas homologadas, o mesmo valendo 
para os Estados com zoneamento ecológico econômico aprovado, e no percentual de $65 \%$ (Art. 12, $\S \S 4^{\circ}$ e $5^{\circ}$ ).

Dessa forma, o Poder Público Federal poderá reduzir, para fins de regularização de imóveis rurais consolidados situados em área de floresta na Amazônia Legal, para 50\% a área de Reserva Legal. Por outro lado, o Poder Público Federal poderá ampliar as áreas de Reserva Legal em até $50 \%$ dos percentuais previstos pelo novo Código, para cumprimento de metas nacionais de proteção à biodiversidade ou de redução de emissão de gases de efeito estufa (Art. 13, II). Esta mudança não tem caráter de inovação, pois a possibilidade de manejo em Reserva Legal, com áreas reduzidas ou ampliadas, já estava prevista no Código anterior.

Uma grande mudança é que o novo Código previu a possibilidade do cômputo das APP no cálculo da área de Reserva Legal, o que pela legislação anterior não era permitido. Deve-se observar, para que tal medida não cause desmatamento, se a APP estiver conservada ou em recuperação e se o imóvel estiver registrado no Cadastro Ambiental Rural (CAR).

O código atual define as providências iniciais que o produtor rural deve tomar para se adequar à legislação, uma delas diz respeito à inscrição do Cadastro Ambiental Rural (CAR). O CAR foi estabelecido em nível nacional com a publicação do Código Florestal, seguida pelos Decretos $n^{\circ} 7.830 / 2012, n^{\circ} 8.235 / 2014$ e da Instrução Normativa MMA n 2/2014. Com a publicação no Diário Oficial através da lei $n^{\circ} 13.335 / 2016$, estende o prazo para a realização do CAR, para 31 de Dezembro de 2017. O CAR é uma ferramenta do processo de regularização ambiental, ou seja, um registro público eletrônico de âmbito nacional, que demonstra se o imóvel está regular ambientalmente ou em processo de regularização dos compromissos previstos no Código Florestal relativos à APP e RL.

O novo Código também prevê incentivos à regularização ambiental dos imóveis rurais. Os proprietários que foram autuados por multas, poderão obter sua suspensão se recuperarem as APPs e a área de Reserva Legal.

A adesão ao Programa de Regularização Ambiental (PRA) faz com que o proprietário rural assine um termo de adesão e compromisso, no qual serão especificados os procedimentos de recuperação a serem adotados. Durante o cumprimento deste termo, o proprietário rural não poderá ser novamente autuado. Contudo, no caso de descumprimento, o termo de adesão terá eficácia de título executivo extrajudicial, viabilizando a execução das multas suspensas.

A criação da Cota de Reserva Legal (CRA) foi um grande avanço nesta Lei, sendo o título que representa a área de Reserva Legal em excesso em uma propriedade rural. Tal título será emitido pelo órgão ambiental a pedido do proprietário da área preservada. A CRA pode ser vendida ou cedida a outro proprietário que tenha déficit de Reserva Legal. A CRA poderá ser cancelada a pedido do proprietário, desde que assegurada outra reserva para o imóvel, ou por decisão do órgão ambiental no caso de degradação da vegetação nativa vinculada ao título (BRASIL, 2012).

A regularização da Reserva Legal também pode ser feita sem a adesão ao PRA. Para isso, o proprietário do imóvel pode conduzir a regeneração natural da vegetação dentro do imóvel ou fazer a compensação, que pode ocorrer de três formas: aquisição da CRA, arrendamento da área sob regime de servidão ambiental, doação ao poder público de área localizada em unidade de conservação pendente de regularização fundiária.

As áreas usadas para compensar a reserva devem ter a mesma extensão que a área a ser compensada e estar localizadas no mesmo bioma da reserva, mesmo que em outro estado. Caso o proprietário rural queira recompor a vegetação no seu imóvel, o prazo é de até vinte anos, a critério do órgão ambiental. O replantio 
poderá ser feito com espécies nativas e exóticas (estas no limite de 50\%) em sistema agroflorestal. O plano de manejo florestal sustentável poderá permitir a exploração econômica da área de Reserva Legal (BRASIL, 2012). É importante ressaltar que aqueles que mantém Reserva Legal em percentuais menores, mas em conformidade com a exigência da lei em vigor à época da averbação da Reserva, ficarão isentos de recompor a área conforme os índices exigidos atualmente. Tal medida garante a segurança jurídica para os proprietários que se mantiveram dentro da lei.

O Novo Código exige o licenciamento ambiental para a exploração de florestas nativas, que será feita com base em Plano de Manejo Florestal Sustentável (PMFS) que deverá prever mecanismos de controle de cortes, da regeneração e do estoque existente. Ficam isentos do PMFS o corte autorizado para uso do solo para agropecuária, o manejo de florestas plantadas fora da reserva legal e a exploração não comercial realizada pelas pequenas propriedades e agricultores familiares. Já as empresas que utilizem grande quantidade de matéria prima florestal deverão elaborar um Plano de Suprimento Sustentável (PSS) com indicação das áreas de origem da matéria prima e cópia do contrato de fornecimento (BRASIL, 2012).

\section{CONSIDERAÇÕES FINAIS}

As mudanças promovidas pelo Novo Código Florestal Brasileiro foram uma tentativa de conciliar, da melhor forma possível, a preservação e a exploração dos recursos naturais, de forma sustentável, sendo assim, atendendo o pressuposto previsto na Constituição Federal de 1988, que prevê um meio ambiente sustentável, em seu Art. 255.

Devido à grande extensão territorial do Brasil e as particularidades de cada região, os impactos ambientais, sociais e econômicos decorrentes da aplicação do código vigente podem ter consequências diferenciadas de acordo com as características locais de cada região.

Percebe-se que ainda existirão muitos debates e dúvidas quanto a aplicação efetiva desta lei, revelando a importância da atuação de profissionais com plenos conhecimentos sobre o Código Florestal, para auxiliar proprietários rurais, instituições e a sociedade como um todo na sua aplicação efetiva.

Após as diretrizes gerais estabelecidas pelo novo código florestal de 2012 , todos os estados da federação deverão elaborar e aprovar seus próprios códigos, dando os devidos detalhamentos e delineando as especificidades regionais, sem haver conflito com o código nacional. Cabe também aos municípios a elaboração dos seus códigos florestais próprios, em consonância com os códigos federal e estadual.

Ao Conselho Nacional do Meio Ambiente (CONAMA) caberá a função de legislar de forma a clarear aspectos do código nacional que necessitem maior detalhamento e ordenação. Cabe também ressaltar as funções de outros órgãos governamentais federais quanto ao trabalho de adequação e atualização do código florestal, como por exemplo, os entes legislativos e judiciários, assim como à sociedade civil organizada, em seu papel crítico e participativo, de atuar no sentido de atualizar e adequar a legislação às necessidades humanas, sempre baseadas em preceitos de sustentabilidade.

A aplicação prática e eficiente do novo código florestal brasileiro também passa pela regulamentação dos programas de incentivos às ações de preservação ambiental, previstos na própria lei.

Afora tudo isso, cabe citar o importante papel dos profissionais da área, os quais devem atuar, dentro dos preceitos da ética profissional e do regramento que 
Ihes cabe, como solucionadores de dúvidas e na elaboração e execução de projetos que contemplem o desenvolvimento socioeconômico do Brasil dentro de preceitos ambientalmente corretos.

\section{REFERÊNCIAS}

ABREU, A. H.; OLIVEIRA, R. Regime jurídico das matas ciliares. Boletim dos Procuradores da República, Brasília, ano 4, n. 48, p. 3-8, 2002.

BORGES, L. A. C.; ReZENDE, J. L. P.; PEREIRA, J. A. A.; JUNIOR, L. M. C.; BARROS, D. A. Áreas de preservação permanente na legislação ambiental brasileira. Ciência Rural, v.41, n.7, p.1202-1210, 2011.

BRANDÃO, J. C. L. Aspectos jurídicos das florestas de preservação permanente e das reservas legais: propriedade e meio ambiente. Revista de Direito Ambiental, v.22, p.114-146, 2001.

BRASIL. Decreto Federal no 23.793, de 23 de janeiro de 1934. Decreta o Código Florestal. Brasília, DF, 1934.

BRASIL, 1965. Lei no 4.771 de 15 de setembro de 1965. Código Florestal. Diário Oficial da República Federativa do Brasil, Poder Legislativo, Brasília, DF, 16 de set. Seção 1. p. 9529-9531.

BRASIL. Lei Federal n‥ 6.746, de 10 de dezembro de 1979. Altera o Estatuto da Terra e dá outras providências. Diário Oficial da República Federativa do Brasil. Brasília, DF, 1979.

BRASIL. Do meio ambiente: artigo 225. In: Constituição Federal de 1988. Brasília, DF, 1988. Cap.6.

BRASIL. Lei no 8.629, de 25 de fevereiro de 1993. Dispõe sobre a regulamentação dos dispositivos constitucionais relativos à reforma agrária, previstos no Capítulo III, Título VII, da Constituição Federal. Diário Oficial da União. Brasília, DF, 26 fev. 1993a, p. 2349.

BRASIL. Medida Provisória 2.166-67, de 24 de agosto de 2001. Altera os arts. $1^{\circ}$, $4^{\circ}, 14,16$ e 44, e acresce dispositivos à Lei oㅜ 4.771 de 1965: Código Florestal. Brasília, DF, 2001.

BRASIL. Constituição da República Federativa do Brasil. Brasília: Senado Federal, 2006.

BRASIL. Lei № 12.651 de 25 de maio de 2012. Institui o Código Florestal. Diário Oficial da República Federativa do Brasil. Brasília, DF, 2012.

BRASIL. Decreto no 7.830, de 17 de outubro de 2012. Dispõe sobre o Sistema de Cadastro Ambiental Rural, o Cadastro Ambiental Rural, estabelece normas de caráter geral aos Programas de Regularização Ambiental, de que trata a Lei no 12.651, de 25 de maio de 2012, e dá outras providências. 
BRASIL. Decreto no 8.235, de 05 de maio de 2014. Estabelece normas gerais complementares aos Programas de Regularização Ambiental dos Estados e do Distrito Federal, de que trata o Decreto № 7.830, de 17 de outubro de 2012, institui o Programa Mais Ambiente Brasil, e dá outras providências.

CAVEDON, F. S. Função social e ambiental da propriedade. São Paulo: Editora Momento Atual, 2003.

LEUZINGER, M. D. Código florestal: problemas e soluções. In: CONCEIÇÃO, M. C. F. Os quarenta anos do Código Florestal Brasileiro. Rio de Janeiro: EMERJ, p.151-197. 2007.

NINO, L. B.; ANJOS, F. S. Usos da propriedade rural e a nova legislação ambiental no município de Pelotas, RS: uma conciliação viável?. Extensão Rural, Santa Maria, v.22, n.3, jul./set. 2015. Disponível em: <https://periodicos.ufsm.br/extensaorural/article/view/9015/pdf>. Acesso em: 30 maio 2017.

STEPHANES, R. Código Florestal: a lei e considerações. Brasília: Editora Brasília, 2012.

VIANA, E. M. Reserva legal e área de preservação permanente na zona rural: um estudo de negociação entre atores em municípios do Vale do Taquari - RS. 2001. 167 f. Dissertação (Mestrado em Ambiente e Desenvolvimento), Centro Universitário Univates.

VILLAMAYOR, D. As áreas de domínio privado protegidas por lei e a conservação da biodiversidade na região do Taboco - Pantanal - Aquidauana - MS. 2003. 218 f. Dissertação (Mestrado em Desenvolvimento Sustentável) Universidade de Brasília. 